\title{
Polyunsaturated fatty acids in $M$. longissimus thoracis of fattening bulls fed silage of grass or maize
}

\author{
M. Dymnicka ${ }^{1,4}$, J. Klupezyński ${ }^{2}$, A. Lozicki' J. Miciński \\ and $\mathbf{J}$. Strzetelski ${ }^{3}$
}

\author{
Warsaw Agricultural University, \\ 'Department of Animal Nutrition and Feed Science \\ Ciszewskiego 8, 02-786 Warsaw, Poland \\ ${ }^{2}$ University of Warmia and Mazury in Olsztyn, \\ Department of Cattle Breeding \\ Oczaponskiego 5, 10-718 Olsztyn, Poland \\ ${ }^{3}$ National Institute of Animal Production, \\ Department of Animal Nutrition \\ 31-083 Balice, Poland
}

\begin{abstract}
The polyunsaturated fatty acid (PUFA) content of $M$. longissimus thoracis was determined in Hereford, Limousine and Charolais fattening bulls fed concentrate and maize or grass silage as the basic feed for 7 months. The PUFA n-3 content was higher in Charolaise bulls than in other breeds, and was significantly higher in animals fed on grass than on maize silage. The ratio of PUFA n-6/n-3 was the most advantageous in Hereford bulls.
\end{abstract}

KEY WORDS: beef cattle, PUFA, grass silage, maize silage

\section{INTRODUCTION}

The dietary content of saturated fatty acids (SFA), deficiency of polyunsaturated fatty acids (PUFA) and high ratio of PUFA n-6/n-3 are risk factors for human health. Whilc it is difficult to change the proportions of fatty acids in animal fat by genetic methods (Karijord et al., 1982), nutrition is considered an important way of modifying fat quality (De Smet et al., 2000).

The aim of the study was to compare the content of polyunsaturated fatty acids in $M$. longissimus thoracis of young bulls of three beef breeds fed maize or grass silage as the only roughage.

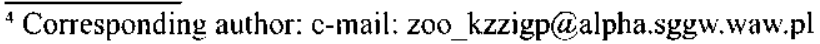




\section{MATERIAL AND METHODS}

The study was performed on 16 bulls of the Limousine (L), 8 Charolaise (Ch) and 9 Hereford $(\mathrm{H})$ breed at 7 months of age and an initial body weight from 215 to 291 $\mathrm{kg}$. The bulls were allotted to two groups and fed for 7 months on rations containing concentrate and either maize (MS) or grass silage (GS) as the only roughage. The rations were prepared according to IZ-INRA (2001) standards assuming a daily gain of $1200 \mathrm{~g}$ for $\mathrm{L}$ and $\mathrm{Ch}$ and $1100 \mathrm{~g}$ for $\mathrm{H}$ bulls.

At the end of the experiment the bulls were slaughtered and their $M$. longissimus thoracis was dissected and sampled for determination of fatty acid content by gas chromatography.

The results were analysed using Statistica 6.0 multifactorial variance analysis and the Duncan test. .

\section{RESULTS AND DISCUSSION}

The total PUFA content in M. longissimus thoracis (Mlt) did not differ statistically among the breeds (Table 1). The Ch bulls had a higher PUFA n-3 content than $L$ but not $H$ bulls. The PUFA $n-6 / n-3$ ratio was the lowest in $H$ and the highest in L bulls ( 3.95 vs 5.41 , respectively), while the optimal ratio recommended by human nutritionists is $2-4$ (Janmes et al., 1998). Differences in the levels of particular PUFA were found among the breeds (Table 1). The highest proportion of C20:5n-3, C18:3n-3 was found in the Mlt of Ch bulls. The contents of C22:5n-3 and C22:6n-3 fatty acids, which have the strongest hypocholesterolemic properties, were higher in Ch than in L bulls. The results point to a breed-related effect on the composition of PUF $\Lambda$ in cattle. According to Malau-Aduli (1997), hereditability of PUFA in cattle is 0.15 .

An effect of silage type on PUFA composition was found in $\mathrm{Ch}$ bulls (Table 2). Feeding grass silage resulted in significantly higher PUFA, PUFA n-6 and $n-3$ contents as compared with maize silage. Also, the contents of C18: $2 n-6, C 18: 3 n-3, C 20: 5 n-3, C 22: 5 n-3$ and C22:6n-3 tended to be higher in $\mathrm{Ch}$ bulls fed on GS than on MS. The higher level of the PUFA n-3 family in GS-fed animals may be related to the fact that the main fatty acid in grass, C18:3 n-3, is a precursor of PUFA n-3 (Marmer, 1997). The higher content of C18:2n- 6 in animals fed on GS may result from the greater amount of concentrate consumed by GS- than MS-fed bulls, the concentration of this acid being high concentrate. Among animals fed MS, the concentration of CLA was higher in $\mathrm{H}$ than $\mathrm{Ch}$ and $\mathrm{L}$ bulls (Table 2). 
TABLE 1 The proportion of polyunsaturated fatty acids in M. longissimus thoracis of bulls, $\%$ of total FA

\begin{tabular}{|c|c|c|c|c|c|}
\hline \multirow{3}{*}{ Fatty acids } & \multicolumn{3}{|c|}{ Breed } & \multicolumn{2}{|c|}{ Type of feeding } \\
\hline & $\mathrm{H}$ & $\mathrm{CH}$ & $\mathrm{L}$ & MS & GS \\
\hline & 9 & 8 & 16 & 18 & 15 \\
\hline C18:2n-6 & 8.30 & 10.76 & 10.51 & 9.39 & 10.66 \\
\hline$C 18: 3 n-3$ & $0.94^{\mathrm{k}}$ & $1.44^{\prime \prime}$ & i. 10 & 1.05 & 1.23 \\
\hline$C 20: 3 n-6$ & 0.69 & 0.74 & 0.70 & 0.64 & 0.78 \\
\hline C20:5n-3 & 0.65 & $0.68: 1$ & $0.46^{h}$ & 0.50 & 0.64 \\
\hline C $22: 5 n-3$ & 1.40 & $1.52^{\mathrm{a}}$ & $1.06^{\mathrm{b}}$ & 1.16 & 1.37 \\
\hline$C 22: 6 n-3$ & 0.19 & $0.20^{\mathrm{a}}$ & $0.14^{\mathrm{h}}$ & 0.15 & 0.18 \\
\hline CLA & 0.32 & 0.26 & 0.25 & 0.29 & 0.24 \\
\hline PUFA & 15.93 & 19.98 & 18.09 & 16.77 & 19.34 \\
\hline PUFA n-6 & 12.67 & 16.03 & 15.23 & 13.81 & 15.80 \\
\hline PUFA n-3 & 3.28 & $3.95^{\prime \prime}$ & $2.85^{1}$ & 2.96 & 3.53 \\
\hline PUFA n-6/n-3 & $3.95^{\mathrm{B}}$ & $4.05^{\prime \prime}$ & $5.41^{\circ}$ & 4.77 & 4.66 \\
\hline
\end{tabular}

means in rows with the different letters differ statistically significant ${ }^{A . R}:(1)-P<0.01$; ${ }^{\text {all }}-\mathrm{P}<0.05$

IABLE 2

The proportion of polyunsaturated fatty acids in $M$. longissimus thoracis of bulls fed different silages, $\%$ of total FA

\begin{tabular}{|c|c|c|c|c|c|c|}
\hline \multirow{2}{*}{$\begin{array}{l}\text { Breed } \\
\text { Doses }\end{array}$} & \multicolumn{2}{|c|}{ Hereford $(\mathrm{H})$} & \multicolumn{2}{|c|}{ Charolaise $(\mathrm{CH})$} & \multicolumn{2}{|c|}{ Limousine (L) } \\
\hline & MS & GS & MS & GS & MS & GS \\
\hline Number & 5 & 4 & 4 & 4 & 9 & 7 \\
\hline C.18:2n-6 & 8.3 & 8.3 & $8.6^{b}$ & $13.6^{\prime \prime}$ & 10.3 & 10.8 \\
\hline C18:3n-3 & 1.0 & 0.87 & $1.1^{\circ}$ & $1.9^{\mathrm{a}}$ & 1.0 & 1.1 \\
\hline$C 20: 3 n-6$ & 0.68 & 0.68 & 0.60 & 0.92 & 0.64 & 0.78 \\
\hline$C 20: 5 n-3$ & 0.65 & 0.64 & $0.50^{\mathrm{B}}$ & $0.93^{A}$ & 0.42 & 0.51 \\
\hline$C 22: 5 n-3$ & 1.48 & 1.28 & $1.25^{\prime \prime}$ & $1.88^{\mathrm{a}}$ & 0.95 & 1.21 \\
\hline$c 22: 6 n-3$ & 0.19 & 0.18 & $0.14^{\mathrm{B}}$ & $0.27^{\wedge}$ & 0.14 & 0.15 \\
\hline CLA & $0.40^{\mathrm{A}}$ & $0.22^{\mathrm{B}}$ & 0.29 & 0.21 & 0.25 & 0.27 \\
\hline PUFA & 16.32 & 15.45 & $16.15^{\mathrm{h}}$ & $25.09^{\prime}$ & 17.30 & 19.10 \\
\hline PUFA n-6 & 12.90 & 12.37 & $13.05^{\mathrm{h}}$ & $19.99^{a}$ & 14.65 & 15.98 \\
\hline PLFA n-3 & 3.41 & 3.07 & $3.09^{13}$ & $5.10^{4}$ & 2.65 & 3.11 \\
\hline PUFA $n-6 / n-3$ & 3.91 & 4.00 & 4.19 & 3.86 & 5.50 & 5.37 \\
\hline
\end{tabular}

means in rows with the different letters differ statistically significant ${ }^{A . B_{-}} \mathrm{P}<0.01$, ${ }^{\text {th. }}-\mathrm{P}<0.05$

\section{CONCLUSIONS}

The content of PUFA n-3 acids in $M$. longissimus thoracis of fattening bulls depends on the breed and is higher in Charolaise than in Limousine and Hereford. The effect of silage type on fatty acid composition seems to depend on the breed, as observed in Charolaise bulls. Feeding grass to this breed resulted in a higher level of PUFA $n-3$ acids than feeding maize silage. 


\section{REFERENCES}

De Smet S., Webb E.C., Claeys E., Uytterhaegen I.., Demeyer I.D., 2000. Effect of dietary encrgy and protein levels on fatly acid composition of intramuscular fat in double-muscled Belgian Blue bulls. Meat Sci. 56, 73-79

Janmes P.T., Ferro-Luzzi A., Isaksson B., Szostak W.B., 1988. Ilealthy nutrition. Preventing nutritional-related discase in Europe. WIIO Regional Publications, Luropeans Series, 24

Karijord O., Standal N., Syrstad 0., 1982. Sources of variation in composition of milk fat. Z. Tierzucht. 7uchtbiol. 99, 81-93

Malau-Aduli A.E.O.. Siebert B.D., Bottema C.D.K.. Pitchford W.S.. 1997. A comparison of fatly acid composition of triacylglycerols in adipose tissue from Limousin and lersey cattle. Aust. J. Agr. Res. 78, 715-722

Marmer W.N., Maxwell R.J., Williams J.E., 1984. Effects of dietary regimen and tissue site on bovine fatty acid profiles. J. Anim. Sci. 59, 109-121

\section{STRESZCZENIE}

Wplyw rasy i rodzaju kiszonki na zawartość wielonienasyconych kwasów tluszczowych w mięśniu longissimus thoracis buhajków trzech ras mięsnych

W doświadczeniu przeprowadzonym na buhajkach rasy Charolaise, Ilereford i Limousine określono wpływ żywienia kiszonką 7 kukurydzy lub 7. traw na zawartość wielonienasyconych kwasów tłuszczowych (PUI $\Lambda$ ) w mięśniu najdłuższym grzbietu (Mlt). 7.wicr/çta zywiono od wieku 7 miesięcy przez następne 7 miesięcy dawkami zlożonymi z paszy treściwej i kiszonck. Lawartość kwasów < rodziny PUFA-n3 w Mlt była wiçksza u buhajków Charolaise niż u pozostałych ras; korzystny wpływ żywicnia kiszonką 7 traw zaznaczył się tylko u buhajków tej rasy. Stosunck PUFA $n-6 / n-3$ był natomiast najwłaściwszy u buhajkow llereford. 